\title{
Trade with California in the Fifties
}

Dr. O. T. Howe has given a Record Book and copies of letters of his esteemed ancestor Captain Octavius Howe to the Business Historical Society. These letters were used by Dr. Howe in his book Argonauts of "49-History and Adventures of the Emigrant Companies from Massachusetts 1849-1850 (Cambridge, Harvard University Press, 1923), and also in the unpublished biography he has prepared of Captain Howe. The letters in question deal with Captain Howe's exploits in taking the brig $T$ igress and her cargo around the Horn to San Francisco, and his attempts to dispose of her cargo, in the early fifties.

Captain Howe and his associates, Captain James Bryant and Ezra Foster of Beverly, and W. H. Hunt of Salem, hoped to repeat in $1850-51$ the successful voyage of the bark Eliza which had disposed of her cargo to great advantage in '49. After the purchase of the brig Tigress (built in Boston, 1829 , of 157 tons register) she was sent to Beverly and there loaded with the most amazing assortment of articles imaginable. "The purchasing agent or agents seem to have bought a little of everything the stores of Beverly could furnish and without much regard to quality.... Thus the Tigress, with a cargo invoiced at $\$ 17,419$, became a veritable floating department store, stocked with everything the heart of man could desire except alcoholic liquor." She cleared from the Port of Salem at Beverly, August 19, I850, with a crew which probably all came from Beverly or vicinity, and one passenger. The trip, which lasted 166 days, was uneventful. One of the last items in the log book was "everything going our way passes us," which no doubt referred to the clipper ships, for Captain Howe later writes to the partners that "the trade to California and China will soon be monopolized by clipper ships." Some of these clippers were advertised to make the trip around the Horn in from 96 to I Io days. An article on this subject appeared in the Bulletin in May, $193^{\circ}$ (Vol. 4, no. 3, whole no. 25).

On February 16, 1851, two weeks after his arrival in San Francisco, Captain Howe, in a letter to Captain Bryant, who was general agent of the company, reported: "I found on my arrival the market to be extremely dull.... I went to Sacramento and as far up as Nickolaus to consult my brother (Captain Edward Howe, who was engaged in real estate business there) and decide for myself and 


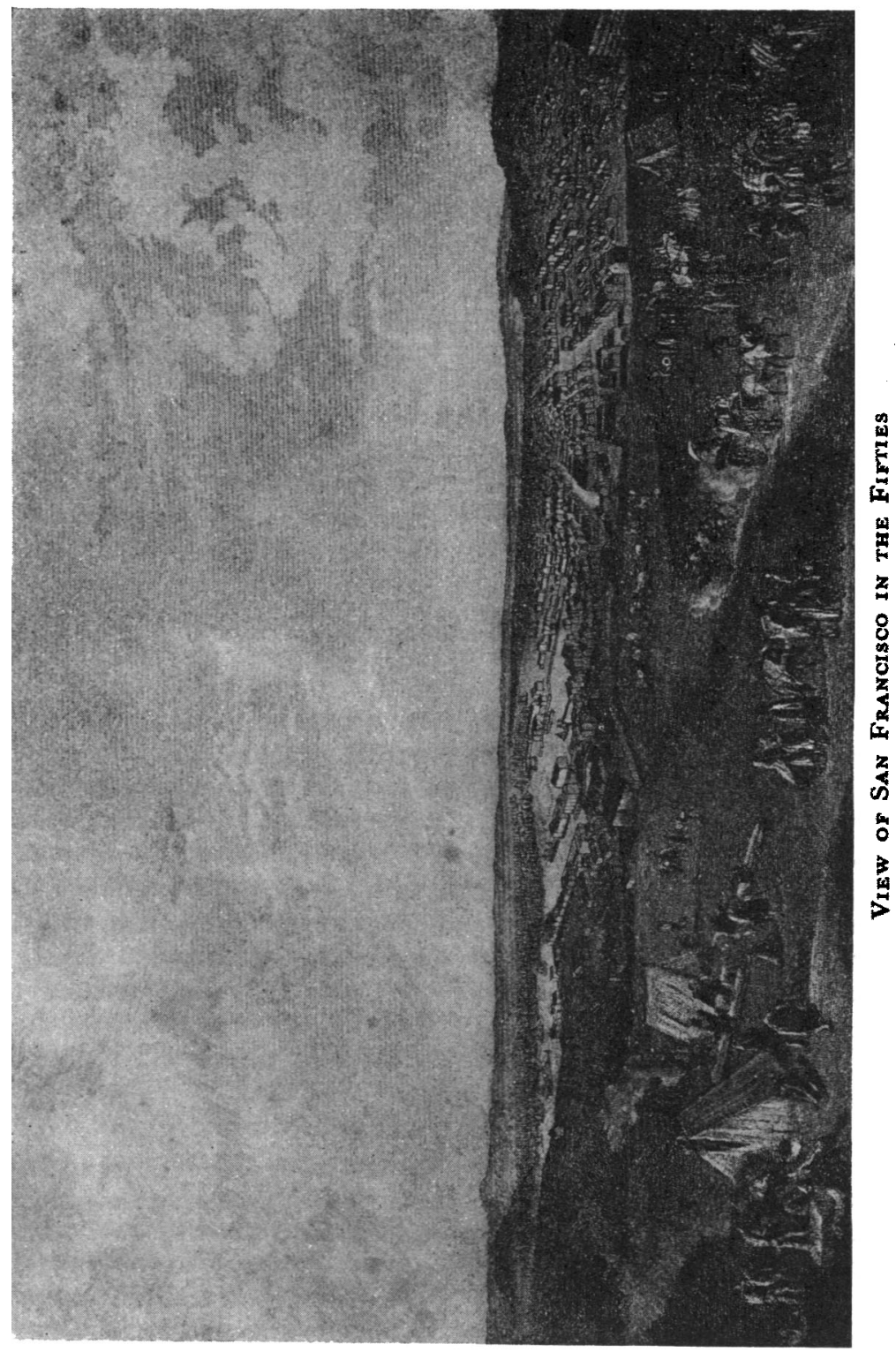

[10] 
came to the conclusion that we should be as well off or better in San Francisco.... The whole country is full of goods and large arrivals are expected. All kinds of trade are so very uncertain and fluctuating that for my own part I put no reliance on any predictions of great improvement."

On March 22, he wrote again saying that "so far from having any offer made for the vessel and cargo, we find it extremely difficult to sell even a small portion of the cargo at a rate that will pay freight and charges, and some parts of it could not be sold at invoice cost. We have sold a few articles at a small profit. The shot brought ten dollars a bag. Shovels, twenty-six dollars a dozen, axes, thirty-eight dollars a dozen, and smoking tobacco, one hundred and fifty per cent advance. They were the only articles on board which were in demand. Short handled shovels were worth seventy dollars a dozen and one man here is reported to have made $\$ 100$ a day by cutting square shovels into pointed ones, and should we have been loaded with these we would have made our pile. The partners, on hearing of the discouraging state of the market, instructed Captain Howe to go up the river and sell goods to buyers along the bank, and on no account to discharge the cargo on shore because of the fire hazard. This it was impossible to do as the cargo was done up in small packages and to obtain the required items might have necessitated the removal of several tons of goods.

Despite the fact that the quality of the cargo was not good, that the seeds were not packed in air tight cans and could not be sold, that the bread and rice were spoiled by weevils, that the butter was "like lard," and the boots, shoes, paints and oils all sold at a sacrifice, nevertheless receipts for the sale of the brig (which brought $\$ 900$ ) and the cargo, up to August 3 I st, which was a few days before Captain Howe left for home, totaled $\$ 18,303$. There were still some goods in the hands of Eldridge and Pausland, Commission Merchants, but the adventure was not a financial success. In his last letter home, Captain Howe in discussing the possibility of following up the trade said: "It is not probable that there will ever be so large profits made as has been the case hitherto, neither will it pay to send vessels here and throw them away as is the case now.... The vessel must calculate on freight home as well as outward."

This was not a unique case by any means, as the glut, caused by the fact that the whole world was competing for the new market, was unparalleled. Some of the ships did not even discharge their cargoes and others dumped them on the beach or sold them for a 
"song." Many of the companies were unable to dispose of the vessels or engage sailors to man them for the return voyage, with the result that they were abandoned in the harbor.

While Captain Howe was in San Francisco, stirring events were taking place. The city, which had a fluctuating population of nearly 3,000 people, was a veritable conglomeration of nationalities, of which number many were Chilians, Peruvians, Mexicans and Australians. The buildings were shacks and makeshifts. Large contingents pitched tents where the Presidio now stands, or on the beach. Every other building was a gambling house. It was said to cost $\$ 10$ a day to live in the city, but one could earn a fortune at any trade. Clerks, for example, were drawing $\$ 300$ per month!

The city was overstocked with goods. In 1850 it was estimated that the amount of chewing tobacco was sufficient to supply every inhabitant for sixty-five years. There were fifty pairs of boots and shoes for each person. "There was," also, according to an account in Argonauts of '49, "enough cloth so that if every man in the city was a tailor and worked for one year making clothes, there would still have remained a surplus."

(It is hoped that the Dibblee papers, the recent gift of Harrison and Benjamin H. Dibblee of San Francisco, will soon be available so that an article giving the story of a San Francisco merchant at this period may be published in the next edition of the Bulletin.)

\section{Mathew Carey and the Depression of 1820}

IN these turbulent times when economists and business men alike find it difficult to solve the business depression which has descended on our complex civilization, it is refreshing to turn to the early economic tracts which were published in this country, and to contemplate the relatively simple panaceas which were advanced by their authors for a correction of the evils of the time. Again, it is a consolation to turn the pages of history and realize that we are not suffering from any unique "disease." In fact in 1820 the outlook was quite as dark as it is today. The productive industry of from sixty to eighty thousand people was destroyed. The cotton planters had suffered a loss of approximately eight million dollars in profits, and the merchants, eleven and a half million dollars, by the fall in cotton prices. Flour was selling at such a low figure that the farmers had but a meagre return for their efforts. The fall in 